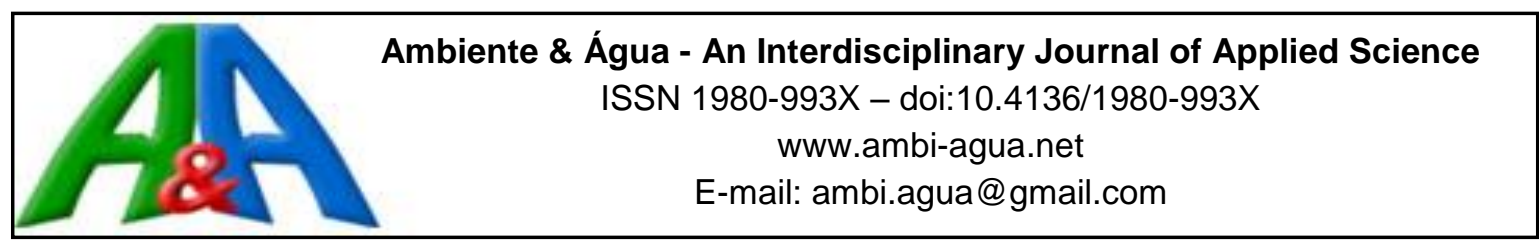

\title{
Autochthonous microalgae cultivation with anaerobic effluent: isolation of strains, survivorship, and characterization of the produced biomass
}

\author{
ARTICLES doi:10.4136/ambi-agua.2362
}

Received: 19 Dec. 2018; Accepted: 26 May 2019

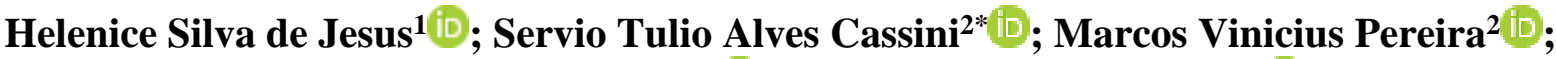 \\ Aline Figueredo Dassoler ${ }^{2}$; Ricardo Franci Gonçalves ${ }^{2}$ iD \\ ${ }^{1}$ Instituto Federal de Educação, Ciência e Tecnologia da Bahia (IFBA), Salvador, BA, Brasil \\ Departamento de Química. E-mail: helenicest@yahoo.com.br \\ ${ }^{2}$ Universidade Federal do Espírito Santo (UFES), Vitória, ES, Brasil \\ Departamento Engenharia Ambiental. E-mail: casinist@gmail.com, \\ marcos.lavagnoli@hotmail.com, aline.dassoler@hotmail.com,rfg822@gmail.com \\ *Corresponding author
}

\begin{abstract}
Six Chlorophyta strains were isolated from the effluent of an anaerobic reactor treating municipal wastewater and identified as Desmodesmus sp. L02, Chlorococcum sp. L04, Coccomyxa sp. L05, Chlorella sp. L06, Scenedesmus sp. L08 and Tetradesmus sp. L09. The microalgae strains were cultivated in unsterilized wastewater under laboratory conditions to determine their potential to survive under non-sterile conditions. The strains were also cultivated in sterilized wastewater in order to analyze their nutrient removal potential and characterize the produced biomass. Amongst the isolated microalgae, Chlorella sp. L06 had the highest survivorship percentage (90\%) for ten days of culture, whilst Desmodesmus sp. L02 had the lowest, not exceeding $1.8 \%$ after $24 \mathrm{~h}$ of inoculation. The dried biomass of the isolates showed an average of $28.7 \%$ of protein, $15.4 \%$ of lipids and $14.8 \%$ of carbohydrates, with Chlorococcum sp. L04 reaching $29.3 \%$ of carbohydrates. In terms of nutrients, nitrogen removal varied from 59.2 to $93 \%$, and phosphorus removal ranged from 79.1 to $95.4 \%$, with Tetradesmus sp. L09 being the most efficient strain.
\end{abstract}

Keywords: anaerobic effluent, microalgae, survivorship.

\section{Cultivo de microalgas nativas com efluente anaeróbio: isolamento de cepas, sobrevivência e caracterização da biomassa algácea}

\section{RESUMO}

Seis cepas de Chlorophyta foram isoladas do efluente de um reator anaeróbio tratando esgoto sanitário e identificadas como Desmodesmus sp. L02, Chlorococcum sp. L04, Coccomyxa sp. L05, Chlorella sp. L06, Scenedesmus sp. L08 e Tetradesmus sp. L09. As cepas de microalgas foram cultivadas em efluente não-esterilizado em condições de laboratório para determinar os potenciais de sobrevivência sob condições não estéreis. As cepas também foram cultivadas em efluente esterilizado para avaliar os potenciais de remoção de nutrientes e caracterizar bioquimicamente a biomassa produzida. Entre as microalgas isoladas, Chlorella 
sp. L06 teve a maior porcentagem de sobrevivência (90\%) por dez dias de cultura, enquanto Desmodesmus sp. L02 apresentou o menor valor, não excedendo 1,8\% após $24 \mathrm{~h}$ de inoculação. A biomassa seca dos isolados apresentou uma média de 28,7\% de proteína, 15,4\% de lipídios e 14,8\% de carboidratos, com Chlorococcum sp. L04 atingindo 29,3\% de carboidratos. Em termos de nutrientes, a remoção de nitrogênio variou de 59,2 a 93\%, e a remoção de fósforo variou de 79,1 a 95,4\%, com Tetradesmus sp. L09 sendo a cepa mais eficiente.

Palavras-chave: efluente anaeróbio, microalgas, sobrevivência.

\section{INTRODUCTION}

Since their inception, wastewater treatment plants (WWTPs) have had a fundamental role in minimizing the impact on water environments on a global level. Until recent years, WWTPs have been implemented with the single objective of protecting the health of humans and the environment. Nevertheless, a paradigm change is occurring in the universe of wastewater treatment, changing the emphasis on the treatment to the focus on recovering the various resources within the wastewater, such as water and nutrients (Puyol et al., 2017). Microalgaebased technologies are perfect candidates to fulfil the aforementioned objectives, considering that these microorganisms grow rapidly, can be cultivated on non-arable lands using wastewaters, promote $\mathrm{CO}_{2}$ sequestration and can be used to polish several types of effluents.

However, the cultivation of microalgae in wastewater effluents is not a new subject, considering that Oswald and Gotaas (1957) first proposed it in the 1950s, and in the decades since, high-rate algal ponds (HRAPs) have been widely studied - only with the purpose of treating wastewater. The algal biomass produced in these systems has not been traditionally recovered to use as feedstock for bioenergy production, specifically due unsatisfactory productivities and the fact that there are no low-cost and effective harvesting technologies.

Conventionally, microalgae biomass production systems use chemical fertilizers and clean water from the distribution grid, and consequently the high costs for the cultivation are one of the main bottlenecks of microalgae-to-biofuel systems in real scale (Brasil et al., 2017). For this reason, most of the scientific community assumes that to reduce the environmental impacts and improve the economic viability of microalgae-to-biofuel processes, alternative sources of water and nutrients must be used. In fact, numerous authors have already reached high biomass productivities when cultivating microalgae in wastewaters, as evidenced by a recent review on the subject ( $\mathrm{Lv}$ et al., 2017).

Cho et al. (2017) discuss that microalgae that are indigenous to the type of wastewater used as medium could display higher adaptability to grow and remove nutrients from it. However, most studies focus on strains from Microalgae Culture Collections, ignoring the microalgal diversity that is already present in the wastewater. Therefore, this study had the primary objective of isolating microalgae strains from the effluent of a UASB reactor treating municipal sewage, in order to cultivate them in non-sterile wastewater and analyze their survivorship potential. The strains were also cultivated in sterilized wastewater in order to determine their growth, nutrient removal potential and to analyze the biochemical properties of the produced biomass.

\section{MATERIALS AND METHODS}

\subsection{Microalgae isolation and identification}

To isolate each strain, borosilicate flasks were filled with the unfiltered effluent from an upflow anaerobic sludge blanket reactor (UASB) treating municipal wastewater, located at an experimental WWTP in the Federal University of Espírito Santo (UFES), closed with cotton 
leads and exposed to indirect sunlight for 15 days to stimulate the growth of autochthonous microalgae and other microorganisms. After this period, the raw effluent turned green due to the multiplication of naturally present microalgae cells, which were favored by the environmental change from complete darkness (inside the reactor) to indirect sunlight. Samples from these mixed cultures were used for the isolation procedures, namely the micropipette method followed by the streak plating technique until unialgal colonies were obtained, according to Andersen and Kawachi (2005). The streak plates were incubated with the following conditions: temperature of $27 \pm 3^{\circ} \mathrm{C}$; luminosity of $80 \mu \mathrm{mol} \mathrm{m} \mathrm{m}^{-2} \mathrm{~s}^{-1}$; and $12 \mathrm{~h} / 12 \mathrm{~h}$ (light/dark) photoperiod. Isolated colonies were kept in liquid sterile effluent media and on agar effluent plates and incubated with the same conditions as the streak plates. Further information on the isolation, identification and maintenance procedures applied herein can be found in Pereira et al. (2018).

\subsection{Effluent sampling and analysis}

The effluent was sampled, filtered with glass fiber membrane filters $(\mathrm{GF} / \mathrm{C} ; 1.2 \mu \mathrm{m}$ pore size) and analyzed for $\mathrm{pH}$, volatile solids, chemical oxygen demand (COD), total Kjeldahl nitrogen (TKN) and total phosphorus (TP), according to the Standard Methods for the Examination of Water and Wastewater (APHA et al., 2005).

The main characteristics of the unsterilized filtered effluents (UFE) throughout the experiments $(\mathrm{n}=3)$ were: $28.8 \pm 1.5 \mathrm{mg} \mathrm{L}^{-1}$ for $\mathrm{TKN} ; 5.0 \pm 0.7 \mathrm{mg} \mathrm{L}^{-1}$ for TP; $208 \pm 16 \mathrm{mg} \mathrm{O}_{2} \mathrm{~L}^{-1}$ for COD; and $\mathrm{pH}$ of 7.6. On the other hand, the autoclaved filtered effluents (AFE) had: $23.5 \pm 1.4 \mathrm{mg} \mathrm{L}^{-1}$ of TKN; $5.6 \pm 0.6 \mathrm{mg} \mathrm{L}^{-1}$ of TP; $162 \pm 10 \mathrm{mg} \mathrm{O}_{2} \mathrm{~L}^{-1}$ of COD and $\mathrm{pH}$ of 10 .

\subsection{Survivorship of the isolated strains in unsterilized filtered effluent (UFE)}

To verify the survivorship potential of the isolated strains, Erlenmeyer flasks $(50 \mathrm{~mL})$ were filled with $30 \mathrm{~mL}$ of UFE and $1 \mathrm{~mL}$ of each inoculum $(\mathrm{n}=6)$, closed with sterile cotton leads, then incubated with a temperature of $27 \pm 3^{\circ} \mathrm{C}$; luminosity of $80 \mu \mathrm{mol} \mathrm{m} \mathrm{m}^{-2} \mathrm{~s}^{-1}$; and $12 \mathrm{~h} / 12 \mathrm{~h}$ (light/dark) photoperiod over 10 days. Fresh samples were taken daily to determine the cell density (N) with an Improved Neubauer Chamber and a microscope (Carl ZEISS Axioplan-2), using standard counting procedures $(n=3)$. The survivorship potential was determined according to the following Equation 1:

$\%$ Survivorship $=\frac{N \text { of the isolate }}{N \text { of all microalgae }} X 100$

Where the cell density $(\mathrm{N})$ of a determined isolate was divided by the cell density of all the microalgae cells present in the counting fields and multiplied by 100 .

\subsection{Cultivation of the strains, characterization of the biomass and nutrient removal}

Each isolated strain was cultivated in borosilicate glass flasks (22 L capacity) with $20 \mathrm{~L}$ of autoclaved filtered effluent (AFE) and its respective inoculum under the following conditions: temperature of $27 \pm 3^{\circ} \mathrm{C}$; luminosity of $80 \mu \mathrm{mol} \mathrm{m} \mathrm{m}^{-2} \mathrm{~s}^{-1} ; 12 \mathrm{~h} / 12 \mathrm{~h}$ (light/dark) photoperiod and continuous air bubbling $\left(1.5 \mathrm{~mL} \mathrm{~s}^{-1}\right)$. The cultures were monitored daily with an in vivo fluorometer during 14 days in order to establish the growth curves. In vivo chlorophyll $a$ measurements were previously correlated with results from the acetone extraction method 10200-H (APHA et al., 2005) for each microalgae strain. The extraction method was performed with $10 \mathrm{~mL}(\mathrm{n}=3)$ samples and the readings were carried out with a spectrophotometer DR/2000 (HACH).

On the $14^{\text {th }}$ day the biomass was harvested with $250 \mathrm{mg} \mathrm{L}^{-1}$ of $\mathrm{Al}_{2}\left(\mathrm{SO}_{4}\right)_{3}$, centrifuged, dried $\left(60^{\circ} \mathrm{C}\right)$ and pulverized with a pestle and mortar. The liquid phase was filtered with glass 
fiber membrane filters (GF/C; $1.2 \mu \mathrm{m}$ pore size) and analyzed for all the parameters within Section 2.2. in order to determine the nutrient and COD removal potential of each strain. The dried biomass was used for the biochemical characterization of lipids, proteins and carbohydrates as in Pereira et al. (2018).

\section{RESULTS AND DISCUSSION}

\subsection{Microalgae isolation and identification}

Microscopic examination of the algal bloom (obtained by incubating natural UASB effluent) showed the presence of several types of green microalgae, diatoms and cyanobacteria, as well as fungi and protozoans. Six Chlorophyta strains were isolated as described in Section 2.1 and identified based on their morphology as Desmodesmus sp. L02, Chlorococcum sp. L04, Coccomyxa sp. L05, Chlorella sp. L06, Scenedesmus sp. L08 and Tetradesmus sp. L09. These six strains were maintained in laboratory according to Lorenz et al. (2005) and were used as inocula for both the survivorship and cultivation experiments.

\subsection{Survivorship of the isolated strains in unsterilized filtered effluent (UFE)}

After the daily cell density monitoring of the cultures, survivorship curves were made for each strain, and the results are depicted in Figure 1.

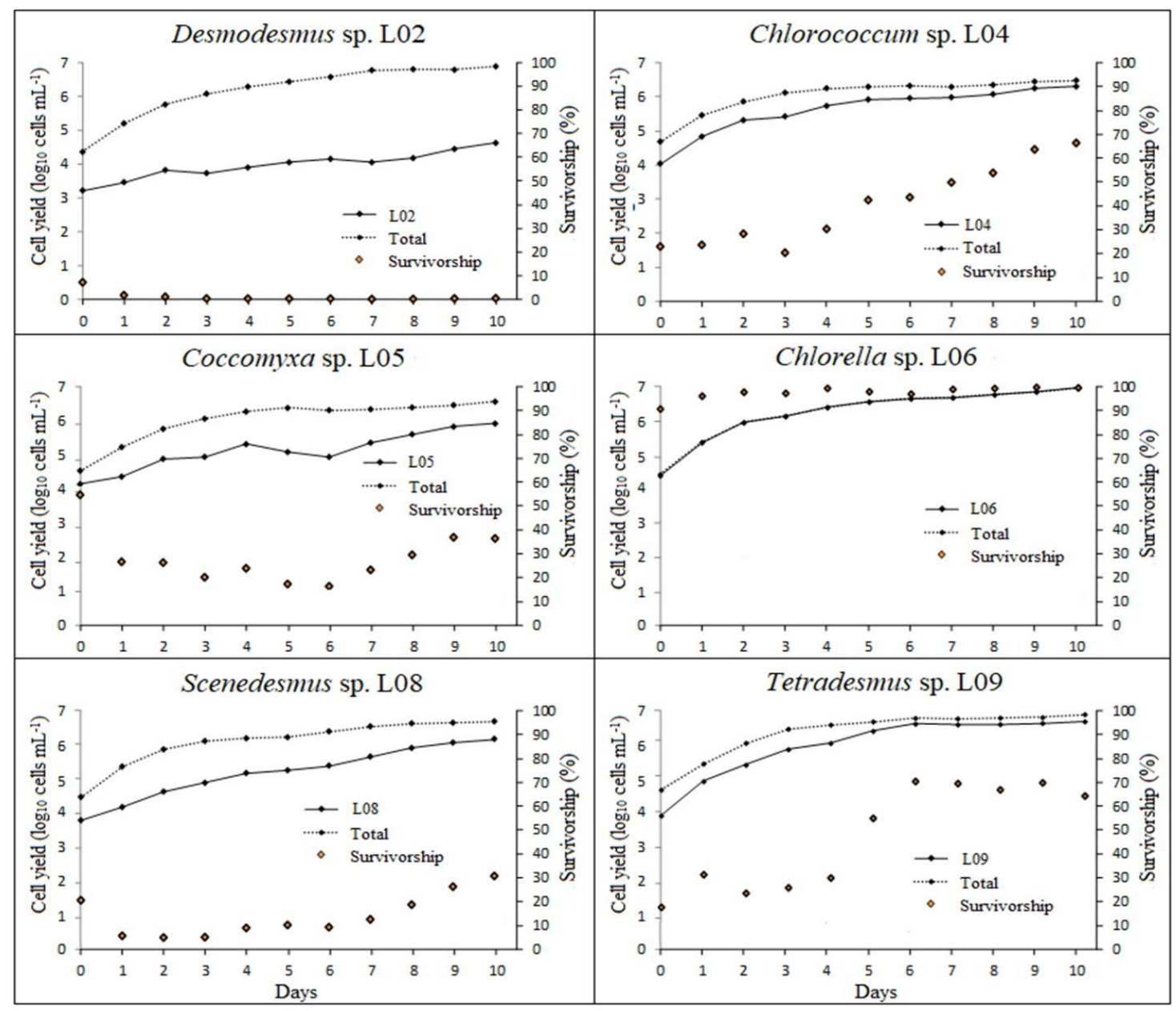

Figure 1. Growth and survivorship curve of six microalgae strains cultured in unsterilized filtered effluent (UFE) in laboratory at a temperature of $27 \pm 3^{\circ} \mathrm{C}$, luminosity of $80 \mu \mathrm{mol} \mathrm{m} \mathrm{m}^{-2} \mathrm{~s}^{-1}$ and $12 \mathrm{~h} / 12 \mathrm{~h}$ (light/dark) photoperiod over 10 days. Dashed lines represent the total cell density, including all microalgae, continuous lines represents the isolate's cell density and the orange diamonds represent the survivorship of the isolate at a given time. 
Results showed that Chlorella sp. L06 was the most adaptable strain, being able to develop and grow in non-sterile wastewater despite the presence of competitors and predators. During the ten days of experiment, this strain had a survivorship of higher than $90 \%$ for each day, with an average of $97.7 \%$. As for the other strains, the mean survivorship value was $1.2 \%$ for Desmodesmus sp. L02, $40.3 \%$ for Chlorococcum sp. L04, $16.3 \%$ for Coccomyxa sp. L05, $14.9 \%$ for Scenedesmus sp. L08 and $47.5 \%$ for Tetradesmus sp. L09.

Although all the strains were isolated from the same wastewater as the one used to cultivate them, it is natural to assume that different strains have different capacities to thrive in a determined environment. Some of them can be weaker competitors, or more susceptible to environmental changes. This seemed to be the case for Desmodesmus sp. L02, due to its inability to develop properly in the UFE medium. On the other hand, Chlorella sp. L06 had the best survivorship results, which was expected, considering that species from the genus Chlorella have been widely used in studies on cultivation of microalgae biomass linked to wastewater treatment (Lv et al., 2017). A study conducted by Mennaa et al. (2015) compared the growth of several microalgae species on non-sterile urban wastewater and obtained better growth results for the Chlorella species, when compared with Scenedesmus species.

Cho et al. (2011) state that the effluents from WWTPs can be used to produce microalgae biomass at a much lower cost, since it does not require nutrient addition, only a pretreatment method such as filtration or UV disinfection for the control of competing microorganisms. The capacity to grow in non-sterile wastewater is a trait that many researchers consider crucial for a microalgae strain, considering the cost reduction in the pretreatment of the wastewater used as media (Guldhe et al., 2017).

\subsection{Growth of the isolated strains in autoclaved filtered effluent (AFE)}

The microalgae strains were cultivated in $22 \mathrm{~L}$ flasks according to Section 2.4. and the growth results, based on chlorophyll $a$, are depicted in Figure 2.

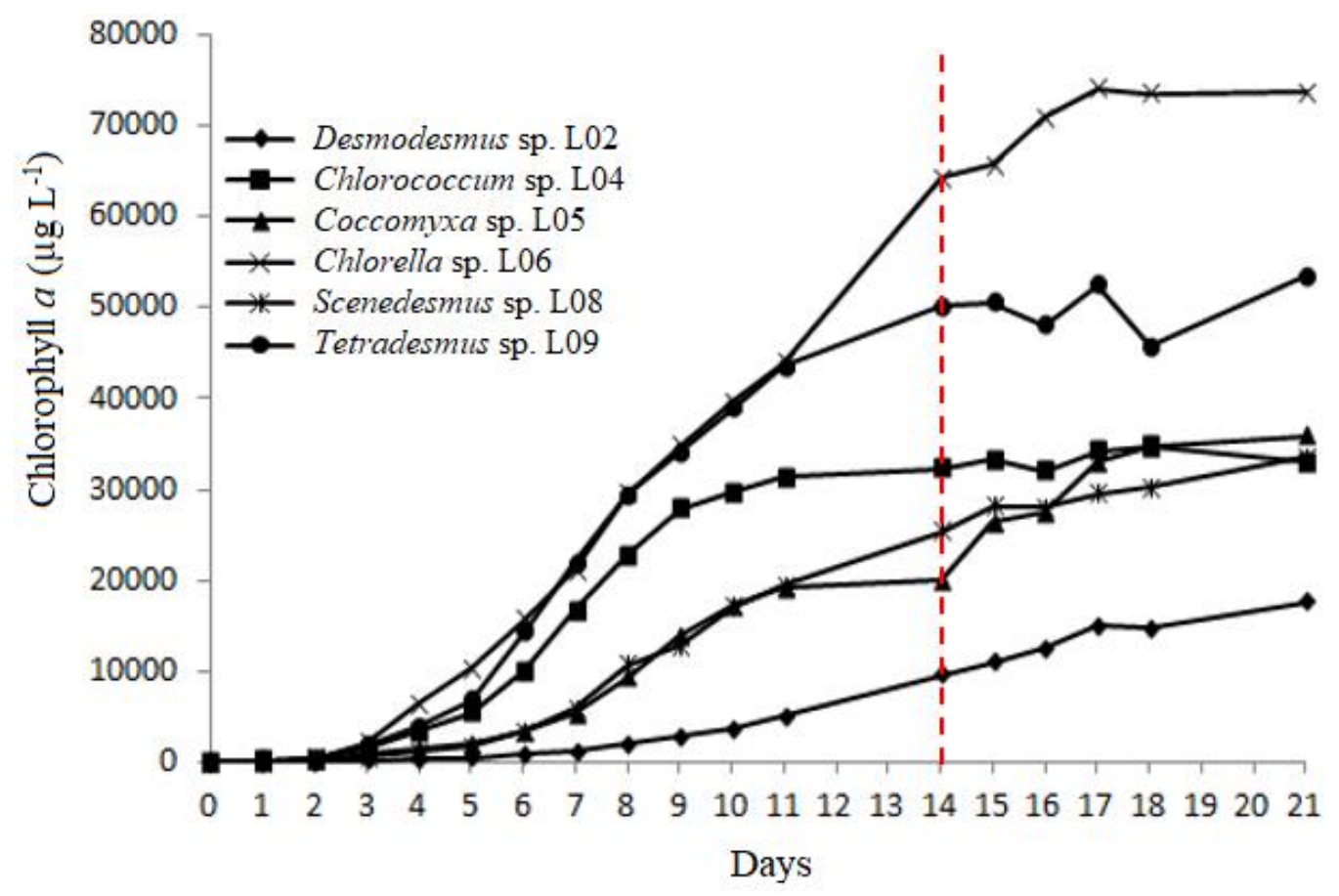

Figure 2. Growth curve, based on chlorophyll $a$, of six microalgae strains cultured in autoclaved filtered effluent (AFE) in laboratory at a temperature of $27 \pm 3^{\circ} \mathrm{C}$, luminosity of $80 \mu \mathrm{mol} \mathrm{m} \mathrm{m}^{-2} \mathrm{~s}^{-1}, 12 \mathrm{~h} / 12 \mathrm{~h}$ (light/dark) photoperiod and air bubbling $\left(1.5 \mathrm{~mL} \mathrm{~s}^{-1}\right)$ over 21 days. The dashed red line represents the day that biomass was harvested from a large sample of the cultures. 
The growth results showed that all the isolated strains were capable of growing in AFE and reaching an exponential growth phase, indicating that this type of medium could support microalgae cultivation, despite the fact that its initial $\mathrm{pH}$ was 10 . Microscopic examination showed that each microalgae culture was clearly dominated by the strain of its respective inoculum. Regarding each strain, Chlorella sp. L06 was not only the most adaptable one in UFE, it was also the strain with the best results on AFE with air bubbling. Following the same trend, Desmodesmus sp. L02 had the least satisfactory growth results, and Tetradesmus sp. L09 was the second best.

\subsection{Biochemical characterization of the produced biomass}

The dried biomass of each microalgae strain was characterized in terms of biochemical composition and the results are shown in Figure 3.

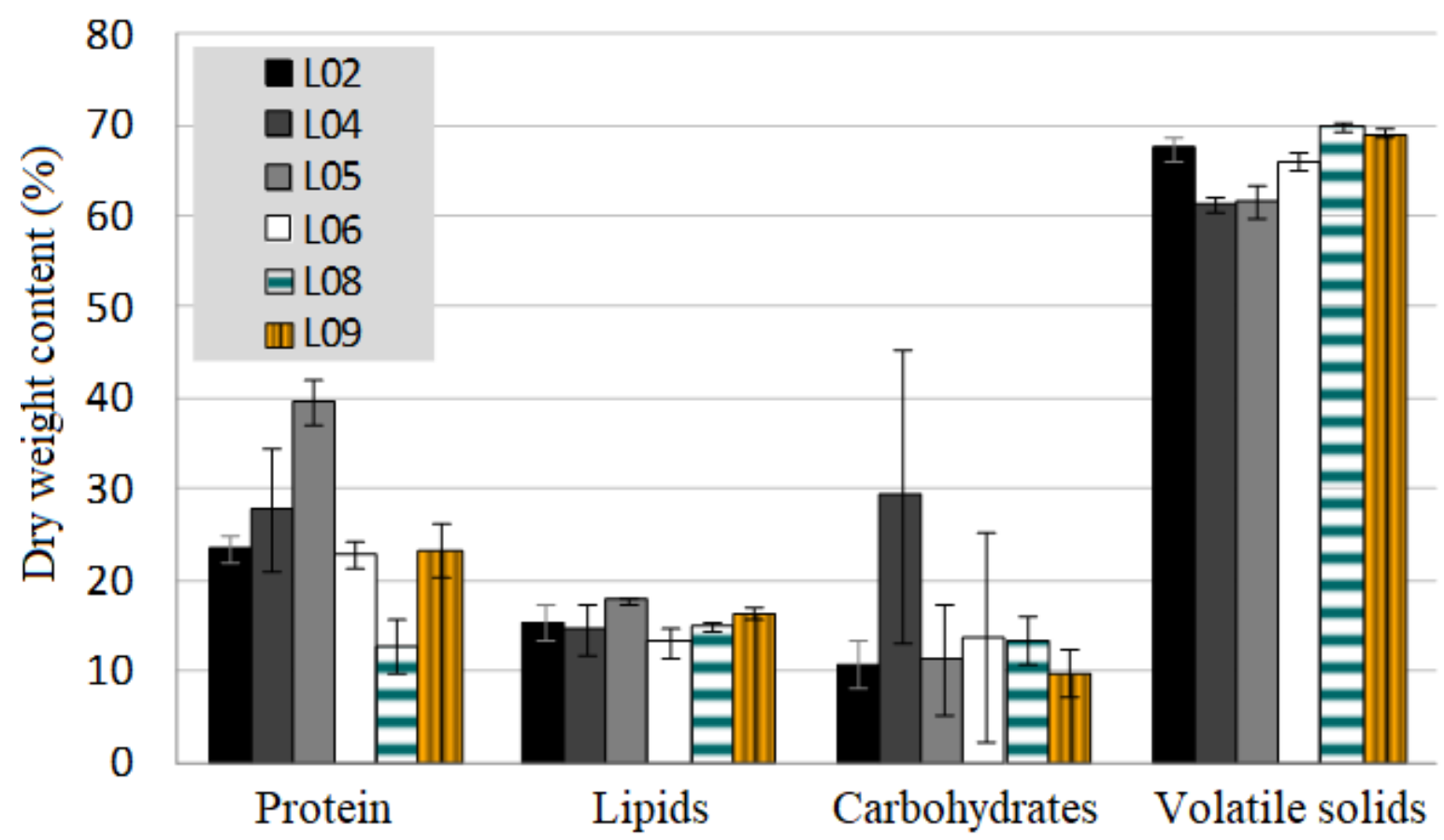

Figure 3. Biochemical composition of the dried biomass for each strain cultivated in autoclaved filtered effluent (AFE) in laboratory at a temperature of $27 \pm 3^{\circ} \mathrm{C}$, luminosity of $80 \mu \mathrm{mol} \mathrm{m}^{-2} \mathrm{~s}^{-1}, 12$ $\mathrm{h} / 12 \mathrm{~h}$ (light/dark) photoperiod and air bubbling $\left(1.5 \mathrm{~mL} \mathrm{~s}^{-1}\right)$ over 14 days (bars represent $\mathrm{SD}$ and $\mathrm{n}=3)$.

The average composition of the biomass was $25.0 \%$ protein, $15.4 \%$ lipids and $14.8 \%$ carbohydrates, all within $66.0 \%$ of volatile solids. It can be observed that the protein content was higher than the other fractions in every case (except for Scenedesmus sp. L08), followed by lipids and carbohydrates. Coccomyxa sp. L05 had the highest protein content amongst the strains (39.7\%) and Scenedesmus sp. L08 had the lowest (12.9\%). Regarding biomass-tobioenergy processes, the anaerobic digestion of the biomass is an attractive alternative to generate biogas within WWTPs that already use anaerobic systems. However, high protein content on the biomass (low $\mathrm{C}: \mathrm{N}$ ratios) is often unfavorable for anaerobic digestion, considering the inhibitory effects that $\mathrm{NH}_{3}$ has over the methanoarchea community (Fricke et al., 2007).

Mutanda et al. (2011) discuss that the co-digestion of the biomass with carbon-rich substrates and the pre-treatment of the biomass are both alternative strategies that can significantly enhance bio-conversion into methane. In fact, Passos et al. (2015) achieved higher methane production when the microalgae biomass was pre-treated with physical methods

Rev. Ambient. Água vol. 14 n. 4, e2362 - Taubaté 2019 
(thermal, microwave and ultrasound). Other than the production of biogas through anaerobic digestion, the biomass can also be used in the production of ethanol through the fermentation of the carbohydrates. In this case, Chlorococcum sp. L04 deserves recognition due to the high carbohydrate content $(29.3 \%)$.

\subsection{Nutrient and COD removal efficiency}

Table 1 shows the nutrient and COD removal efficiency from the liquid phase based on different microalgae cultures after the addition of the coagulant.

Table 1. Nutrients and COD concentration in the liquid phase of the microalgae cultures at the beginning of the experiment (in) and after the addition of the coagulant agent (out). The strains were cultivated in autoclaved filtered effluent (AFE) in laboratory at a temperature of $27 \pm 3^{\circ} \mathrm{C}$, luminosity of $80 \mu \mathrm{mol} \mathrm{m}{ }^{-2} \mathrm{~s}^{-1}, 12 \mathrm{~h} / 12 \mathrm{~h}$ (light/dark) photoperiod and air bubbling $\left(1.5 \mathrm{~mL} \mathrm{~s}^{-1}\right)$ over 14 days $( \pm \mathrm{SD}$ and $\mathrm{n}=3$ ).

\begin{tabular}{lccccccc}
\hline & \multicolumn{7}{c}{ Cultures/Strains } \\
\hline Parameters & Units & L02 & L04 & L05 & L06 & L08 & L09 \\
\hline TKN (in) & $\mathrm{mg} \mathrm{L}^{-1}$ & $26.5 \pm 0.3$ & $26.5 \pm 0.3$ & $26.5 \pm 0.3$ & $26.5 \pm 0.3$ & $26.5 \pm 0.3$ & $26.5 \pm 0.3$ \\
TKN (out) & $\mathrm{mg} \mathrm{L}^{-1}$ & $10.8 \pm 0.3$ & $5.6 \pm 1.0$ & $3.9 \pm 1.8$ & $8.9 \pm 0.8$ & $8.7 \pm 0.3$ & $1.8 \pm 1.3$ \\
TKN removal & $\%$ & 59.2 & 78.9 & 85.3 & 66.4 & 67.2 & 93.2 \\
TP (in) & $\mathrm{mg} \mathrm{L}^{-1}$ & $7.1 \pm 0.2$ & $7.1 \pm 0.2$ & $7.1 \pm 0.2$ & $7.1 \pm 0.2$ & $7.1 \pm 0.2$ & $7.1 \pm 0.2$ \\
TP (out) & $\mathrm{mg} \mathrm{L}^{-1}$ & $1.5 \pm 0.0$ & $0.7 \pm 0.0$ & $0.8 \pm 0.0$ & $0.7 \pm 0.1$ & $0.8 \pm 0.2$ & $0.3 \pm 0.0$ \\
TP removal & $\%$ & 78.9 & 90.1 & 88.7 & 90.1 & 88.7 & 95.8 \\
COD (in) & $\mathrm{mg} \mathrm{L}^{-1}$ & $184 \pm 6$ & $184 \pm 6$ & $184 \pm 6$ & $184 \pm 6$ & $184 \pm 6$ & $184 \pm 6$ \\
COD (out) & $\mathrm{mg} \mathrm{L}^{-1}$ & $93 \pm 0.0$ & $101 \pm 4.0$ & $82 \pm 8.0$ & $64 \pm 5.0$ & $76 \pm 11.0$ & $58 \pm 13.0$ \\
COD removal & $\%$ & 49.4 & 45.3 & 55.3 & 64.9 & 58.7 & 68.3 \\
\hline Abbration
\end{tabular}

Abbreviations: TKN, total Kjeldahl nitrogen; TP, total phosphorus; COD, chemical oxygen demand.

It can be observed that, at the end of the experiment, the TKN removal varied from 59.2\% (Desmodesmus sp. L02) to 93.2\% (Tetradesmus sp. L09). Regarding TP, removal efficiency was higher than $80 \%$ for all cultures (except Desmodesmus sp. L02), with Tetradesmus sp. L09 reaching $95.8 \%$. In terms of $\mathrm{COD}$, it is interesting to note that its concentration was already low at the beginning of the experiment $\left(184 \mathrm{mg} \mathrm{L}^{-1}\right)$, as expected, since secondary treated effluents from anaerobic treatments are generally low in COD and BOD. However, the removal efficiency of this organic fraction still ranged from $45.3 \%$ (Chlorococcum sp. L04) to higher than $68.3 \%$ (Tetradesmus sp. L09). COD removal in this case may have been caused by the high photosynthetic $\mathrm{O}_{2}$ generation inside the flasks, which could enhance the oxidation of organic matter by heterotrophic microorganisms. On the other hand, high COD removal can indicate microalgal mixotrophic nutrition, as discussed by Park et al. (2011). Adsorption by the biomass and or filter membrane may have also contributed to the COD removal, since a fraction of the COD is often recalcitrant, therefore difficult to assimilate biologically.

The results for removal efficiency obtained herein are similar to the ones obtained by Mennaa et al. (2015), and agree with the range of values reported in a recent review study on the subject of microalgae cultivation in secondary-treated wastewaters (Lv et al., 2017). On the other hand, since the $\mathrm{pH}$ of all cultures reached values above 9.0, it might be reasonable to assume that at least part of the nitrogen was lost due to abiotic processes such as ammonia stripping, rather than assimilation by microorganisms (Nurdogan and Oswald, 1995). The same logic can be applied to phosphorus removal due to the chemical precipitation of this nutrient at $\mathrm{pH}$ levels higher than 9.0. Nonetheless, in terms of tertiary treatment, we can conclude that nitrogen, phosphorus and COD were efficiently removed from the liquid phase of the effluent in this experiment. 


\section{CONCLUSIONS}

The results showed that Chlorella sp. L06 and Tetradesmus sp. L09 were able to survive and thrive in unsterilized UASB effluent after inoculation, indicating that they were more adapted to this medium than the other microalgae isolates, in terms of competition for nutrients and resiliency to protozoan grazers. The strains were also cultivated in autoclaved UASB effluent, and all of them were able to grow and reach the exponential growth phase.

The dry biomass of the isolates showed, on average, $66.0 \%$ of volatile solids, of which $25.0 \%$ was composed of proteins, $15.4 \%$ of total lipids and $14.8 \%$ of total carbohydrates. The microalgae cultures were able to remove up to $93 \%$ of nitrogen and $95.4 \%$ of phosphorus from the wastewater's liquid phase, improving the UASB effluent quality and converting these nutrients into biomass that can be used as feedstock for the production of biogas or syngas.

\section{ACKNOWLEDGEMENTS}

The authors would like to express sincere gratitude to the Brazilian fostering agencies FAPES (Fundação de Amparo à Pesquisa e Inovação do Espírito Santo) for financial support and CAPES (Coordenação de Aperfeiçoamento de Pessoal de Nível Superior) for the doctoral scholarship to the first author (Grant 01.13.0092-00).

\section{REFERENCES}

ANDERSEN R. A.; KAWACHI, M. Traditional microalgae isolation techniques. In: ANDERSEN, R. A. (Ed.) Algal culturing techniques. London: Elsevier, 2005. p.83100.

APHA; AWWA; WEF. Standard Methods for the Examination of Water and Wastewater. 21. ed. Washington, 2005.

BRASIL, B. S.; SILVA, F. C.; SIQUEIRA, F. Microalgae biorefineries: the Brazilian scenario in perspective. New Biotechnology, v. 39, n. 1, p. 90-98, 2017. https://doi.org/10.1016/j.nbt.2016.04.007

CHO, S.; LUONG, T. T.; LEE, D.; OH, Y-K.; LEE, T. Reuse of effluent water from municipal wastewater treatment plant in microalgae cultivation for biofuel production. Bioresource $\begin{array}{lllllll}\text { Technology, } & \text { v. } \quad 102, \quad \text { n. } & 1, \quad \text { p. } & 8639-8645, & \end{array}$ https://doi.org/10.1016/j.biortech.2011.03.037

CHO, D.; CHOI, J.; KANG, Z.; KIM, B. H.; OH, H. M.; KIM, H. S.; RAMANAN, R. Microalgal diversity fosters stable biomass productivity in open ponds treating wastewater. Scientific Reports, v. 7, n. 1, 2017. https://dx.doi.org/10.1038/s41598-01702139-8

FRICKE, K.; SANTEN, H.; WALLMANN, R. Operating problems in anaerobic digestion plants resulting from nitrogen in MSW. Waste Management, v. 27, n. 1, p. 30-43, 2007. https://doi.org/10.1016/j.wasman.2006.03.003

GULDHE, A.; KUMARI, S.; RAMANNA, L.; RAMSUNDAR, P.; SINGH, P.; RAWAT, I.; BUX, F. Prospects, recent advancements and challenges of different wastewater streams for microalgal cultivation. Journal of Environmental Management, v. 203, n. 1, p. 299315, 2017. https://doi.org/10.1016/j.jenvman.2017.08.012 
LORENZ, M.; FRIEDL, T.; DAY, J. G. Perpetual maintenance of actively metabolizing microalgal cultures. In: ANDERSEN, R. A. (Ed.). Algal culturing techniques. London: Elsevier, 2005. p.145-156.

LV, J.; FENG, J.; LIU, Q.; XIE, S. Microalgal cultivation in secondary effluent: recent developments and future work. International Journal of Molecular Sciences, v. 18, n. 1, p. 1-18, 2017. https://doi.org/10.3390/ijms18010079

MENNAA, F. Z.; ARBIB, Z.; PERALES, J. A. Urban wastewater treatment by seven species of microalgae and an algal bloom: biomass production, $\mathrm{N}$ and $\mathrm{P}$ removal kinetics and

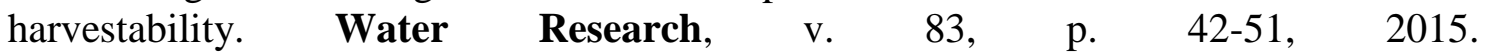
https://doi.org/10.1016/j.watres.2015.06.007

MUTANDA, T.; RAMESH, D.; KARTHIKEYAN, S.; KUMARI, S.; ANANDRAJ, A.; BUX, F. Bioprospecting for hyper-lipid producing microalgal strains for sustainable biofuel production. Bioresource Technology, v. 102, p. 57-70, 2011. https://doi.org/10.1016/j.biortech.2010.06.077

NURDOGAN, Y.; OSWALD, W. J. Enhanced nutrient removal in high-rate ponds. Water Science and Technology, v. 12, p. 33-43, 1995. https://doi.org/10.1016/02731223(95)00490-E

OSWALD, W. J.; GOTAAS, H. B. Photosynthesis in sewage treatment. Transactions of the American Society of Civil Engineers, v. 122, p. 73-105, 1957.

PARK, J. B. K.; CRAGGS, R. J.; SHILTON, A. N. Wastewater treatment high rate algal ponds for biofuel production. Bioresource Technology, v. 102, n. 35, p. 35-42, 2011. https://doi.org/10.1016/j.biortech.2010.06.158

PASSOS, F.; CARRETERO, J.; FERRER, I. Comparing pretreatment methods for improving microalgae anaerobic digestion: Thermal, hydrothermal, microwave and ultrasound. $\begin{array}{lllllll}\text { Chemical Engineering Journal, } & \text { v. 279, p. 667-672, } 2015 .\end{array}$ https://doi.org/10.1016/j.cej.2015.05.065

PEREIRA, M. V.; DASSOLER, A. F.; ANTUNES, P. W.; GONÇALVES, R. F.; CASSINI, S. $\mathrm{T}$. Indigenous microalgae biomass cultivation in continuous reactor with anaerobic effluent: effect of dilution rate on productivity, nutrient removal and bioindicators. $\begin{array}{llll}\text { Environmental Technology, } & \text { p. } & 1-13, & \end{array}$ https://dx.doi.org/10.1080/09593330.2018.1549105

PUYOL, D.; BATSTONE, D. J.; HÜLSEN, T.; ASTALS, S.; PECES, M.; KROMER, J. O. Resource recovery from wastewater by biological technologies: opportunities, challenges, and prospects. Frontiers in Microbiology, v. 7, p. 2106, 2017. https://dx.doi.org/10.3389/fmicb.2016.02106 